\title{
Comparative Study on the Properties of Cement Stabilized Lateritic Bricks Sourced from Different Locations
}

\author{
Adeyemi E. Adetoro ${ }^{1}$, Bamidele I. Faluyi ${ }^{2}$ \\ ${ }^{1}$ Department of Civil Engineering, ${ }^{2}$ Department of Computer Science, \\ The Federal Polytechnic, Ado-Ekiti, Nigeria
}

\section{ABSTRACT}

There is need for tested and proven alternative source of alternative walling materials in third world countries such as Nigeria. This will foster massive provision of houses for the populace. The aim of this research is to compare the properties of cement stabilized lateritic bricks sourced from different locations. Soil samples were taken from three locations within the study area to laboratory for Abrasion, Impact, Compressive strength and Water absorption tests. Results showed that the stabilized lateritic bricks $\mathrm{A}, \mathrm{B}$ and $\mathrm{C}$ have water absorption values varied from 17 to $23 \%, 32$ to $36 \%$ and 38 to $42 \%$ respectively for $7-28$ days at $1 \%$ cement content. For $2 \%$ cement content, water absorption values varied from 15 to $20 \%, 24$ to $28 \%$ and 32 to $36 \%$ for lateritic bricks A, B and C respectively. While sandcrete block has water absorption values varied from 9 to $13 \%$ for $7-28$ days respectively. It is also observed that stabilized lateritic bricks A, B and $\mathrm{C}$ have compressive strength values varied from 1.33 to $1.71 \mathrm{~N} / \mathrm{mm} 2,0.32$ to $0.42 \mathrm{~N} / \mathrm{mm} 2$ and 0.21 to $0.29 \mathrm{~N} / \mathrm{mm} 2$ respectively for $7-28$ days at $1 \%$ cement content. For $2 \%$ cement content, compressive strength values varied from 1.52 to $2.09 \mathrm{~N} / \mathrm{mm} 2,0.40$ to $0.63 \mathrm{~N} / \mathrm{mm} 2$ and 0.29 to $0.35 \mathrm{~N} / \mathrm{mm} 2$ at $7-28$ days for lateritic bricks $\mathrm{A}, \mathrm{B}$ and $\mathrm{C}$ respectively. While sandcrete block has compressive strength values varied from 0.54 to $0.74 \mathrm{~N} / \mathrm{mm} 2$ for 7 to 28 days respectively. The higher the cement content, the lower the absorption rate and the higher the compressive strength. The compressive strength also increases with age. Lateritic brick is more cheaper than sandcrete block for construction of building because it require little cement content. Further study should be conducted for another source of stabilizer.
Keywords: Abrasion; Brick; Compressive strength; Water absorption; Impact.

\section{INTRODUCTION}

Laterite is a Latin word meaning brick. It is a surface formation in hot and wet tropical areas, which is enriched in iron and aluminum and characterized by the intense weathering of bedrock into clay and a variety of oxides. Laterite can be soft and friable as well as firm and physically resistant [1].

Historically, laterite, was cut into brick-like shapes and used in monumental building for its hardness when dried in Nigeria tropical area. Nearly all laterites are rusty-red because of the presence of iron oxides. The red-brown colouration is as a result of weathering of the underlying parent rock. Laterization (Tropical weathering) is a prolonged process of mechanical and chemical weathering, which produces a wide variety in the thickness and grade [3].

Texturally, lateritic soils are largely variable and may contain all fraction sizes; boulders, cobbles, gravel, sand, silt, clay as well as concretionary rocks. Quartz tic gravels, which are formed from the alteration of quartz rich parent rocks, are generally well graded with $20 \%$ of silt and clay-size fractions. Concretionary laterites have a higher content of fines ranging between $35 \%$ and $40 \%$. Foot slope concretionary laterite gravels are coarse and gap graded (less sand) compared to high level gravels [8]. Laterite is soft when water is present, but in the absence of water, it hardens and turns imperviously brick hard [4].

Bricks are made from clay by burning it at high temperatures. The action of heat gives rise to process that causes the clay particles to fuse and develops 
extremely strong ceramic bonds in the burnt clay bodies. Such bonds are highly strong. As a result, bricks can withstand the severe weathering actions and are inert to almost all normal chemical attacks.

Bricks are well known for their high compressive strength, which are governed by the raw materials used, manufacturing process, shape and size. Bricks made by a de-aerated extruder, fired to sufficiently high temperature and can easily withstand a compressive pressure exceeding $28 \mathrm{~N} / \mathrm{mm}^{2}$ [2]. They are suitable for almost all structural and building applications. Past literture works of [1], [2], [3] and [7] among others affirmed lateritic bricks as alternative material for house construction.

In the third world and other developing countries, the use of sandcrete hollow block has dominated the construction industries especially the building industries, where alternative walling unit materials have not gained popularity. This research work focuses on the comparative study of the properties of cement stabilized lateritic bricks and sandcrete hollow blocks. The study will help in pursuing goal of achieving low cost housing for the masses in developing countries such as Nigeria. It is certain that with proven performance of this alternative walling material, many building contractors will embrace the application of bricks as walling units in building construction.

The scope of the study shall be restricted to the investigation of properties of bricks made from lateritic soil collected from the study area, involved series of laboratory tests such as Compressive strength, Water absorption, Impact and Abrasion to know the appropriateness or properties and strength of the cement stabilized lateritic brick.

\section{A. Study Area}

The study area is within the Federal Polytechnic, Ado Ekiti along Ado - Ijan Ekiti road, Ado - Ekiti Local Government Areas (LGA), Ekiti State, South western part of Nigeria. It is around Latitude $7.6056^{\circ} \mathrm{N}$ and Longitude $5.2886^{\circ} \mathrm{E}$ as shown in Fig. 1. The geology of Ekiti State where the study area is situated consists of old plains broken by steep sided outcropping dome rocks and underlain by metamorphic rocks of the Precambrian basement complex of South western Nigeria, which are very old. These showed serious changes in grain size and mineral composition. The rocks are quartz gneisses and schists consisting mainly quartz with small amounts of white mizageous minerals. They vary from very coarse-grained pegmatite to medium-grained gneisses in grain size and structure. They are strongly foliated and occur as outcrops. The soils derived from the basement complex rocks are mostly well drained, having medium to coarse in texture ([5], [6]).

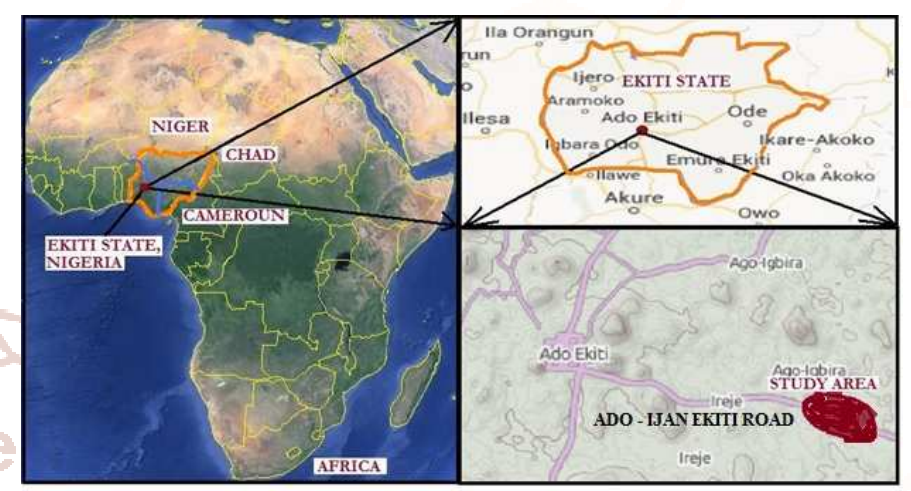

Figure 1: Location of the study area

\section{Materials and Methods}

Lateritic soil samples were obtained by using cutlass (for clearing access path to the sample locations), digger (for digging the earth surface) and shovel was used to excavate the loose soil to the required depth (> $0.80 \mathrm{~m}$ ). Then polythene sample bags were used to collect the lateritic soil samples to retain the original qualities of the soil at random from three locations within the study area. The samples were then taken to the laboratory where the deleterious materials such as roots were removed. The details of the soil samples were as shown in Table 1. Moulding of test specimens was started as soon as possible after completion of identification. Their attributes were also examined. $1 \%$ and $2 \%$ of cement (by weight) were used to stabilize the lateritic soil in producing the bricks. The bricks samples were cured for 7,21 and 28 days. Then compressive strength, absorption, impact and abrasion tests were performed on the cement-stabilized bricks in the laboratory of Civil Engineering Dept., the Federal Polytechnic, Ado - ekiti, Nigeria. All tests were performed to standards in accordance with [4]. The results were then analysed.

TABLE 1: The Details of The Soil Samples

\begin{tabular}{|c|c|c|}
\hline $\begin{array}{c}\text { SAMPLE } \\
\text { CODE }\end{array}$ & LOCATION & DESCRIPTION \\
\hline A & 1 & School Gate \\
\hline B & 2 & Rector's Village \\
\hline C & 3 & Abuja Hostel \\
\hline
\end{tabular}




\section{Results and Discussion}

Table 2 show Compressive strength and water absorption tests results for the lateritic bricks obtained from the locations within the study area and sandcrete block. Their plots were shown in Figure 2. It is observed that stabilized lateritic bricks $\mathrm{A}, \mathrm{B}$ and $\mathrm{C}$ have water absorption values varied from 17 to $23 \%$, 32 to $36 \%$ and 38 to $42 \%$ respectively for $7-28$ days at $1 \%$ cement content. For $2 \%$ cement content, water absorption values varied from 15 to $20 \%, 24$ to $28 \%$ and 32 to $36 \%$ for lateritic bricks A, B and C respectively. While sandcrete block has water
Absorption values varied from 9 to $13 \%$ for $7-28$ days respectively. Thus, sandcrete block has the lowest rate of water absorption. Table 2 and Figure 2, showed that the water absorption rate decreases as number of days increases, Lateritic brick $\mathrm{C}$ has the highest rates of water absorption for both 1 and $2 \%$ cement contents at 7 days. Thus, the higher the cement content the lower the absorption rate. The water absorption rate for the materials were in order of $\mathrm{C}>\mathrm{B}>\mathrm{A}>$ sandcrete for both cement contents values.

TABLE 2: Water Absorption and Compressive Strength Tests Results For The Brick Samples

\begin{tabular}{|c|c|c|c|c|c|c|c|c|}
\hline \multirow[t]{2}{*}{ TEST } & \multirow{2}{*}{$\begin{array}{l}\text { DA } \\
\text { YS }\end{array}$} & \multicolumn{3}{|c|}{$\begin{array}{c}\text { 1\% - CEMIENT } \\
\text { STABILIZED BRICK }\end{array}$} & \multicolumn{3}{|c|}{$\begin{array}{c}2 \% \text { - CEMIENT } \\
\text { STABILIZED BRICK }\end{array}$} & \multirow[t]{2}{*}{$\begin{array}{l}\text { SANDC } \\
\text { RETE }\end{array}$} \\
\hline & & A & B & C & $\mathrm{A}$ & B & C & \\
\hline \multirow{3}{*}{$\begin{array}{c}\text { WATER } \\
\text { ABSORP } \\
\text { TION }\end{array}$} & 7 & 23 & 36 & 42 & 20 & 28 & 36 & 13 \\
\hline & 21 & 19 & 34 & 39 & 17 & 26 & 33 & 11 \\
\hline & 28 & 17 & 32 & 38 & 15 & 24 & 32 & 9 \\
\hline \multirow{3}{*}{$\begin{array}{c}\text { COMPRE } \\
\text { SSIVE } \\
\text { STRENG } \\
\text { TH }\end{array}$} & 7 & 1.33 & 0.32 & 0.21 & 1.52 & 0.4 & 0.29 & 0.54 \\
\hline & 21 & 1.52 & 0.36 & 0.27 & 1.9 & 0.53 & 0.33 & 0.64 \\
\hline & 28 & 1.71 & 0.42 & 0.29 & 2. & 0.63 & 0.35 & 0.74 \\
\hline
\end{tabular}

It is also observed that stabilized lateritic bricks $\mathrm{A}, \mathrm{B}$ and $\mathrm{C}$ have compressive strength values varied from 1.33 to $1.71 \mathrm{~N} / \mathrm{mm}^{2}, 0.32$ to $0.42 \mathrm{~N} / \mathrm{mm}^{2}$ and 0.21 to $0.29 \mathrm{~N} / \mathrm{mm}^{2}$ respectively for $7-28$ days at $1 \%$ cement content. For $2 \%$ cement content, compressive strength values varied from 1.52 to $2.09 \mathrm{~N} / \mathrm{mm}^{2}, 0.40$ to $0.63 \mathrm{~N} / \mathrm{mm}^{2}$ and 0.29 to $0.35 \mathrm{~N} / \mathrm{mm}^{2}$ at $7-28$ days for lateritic bricks $\mathrm{A}, \mathrm{B}$ and $\mathrm{C}$ respectively. While sandcrete block has compressive strength values varied from 0.54 to $0.74 \mathrm{~N} / \mathrm{mm}^{2}$ for 7 to 28 days respectively.

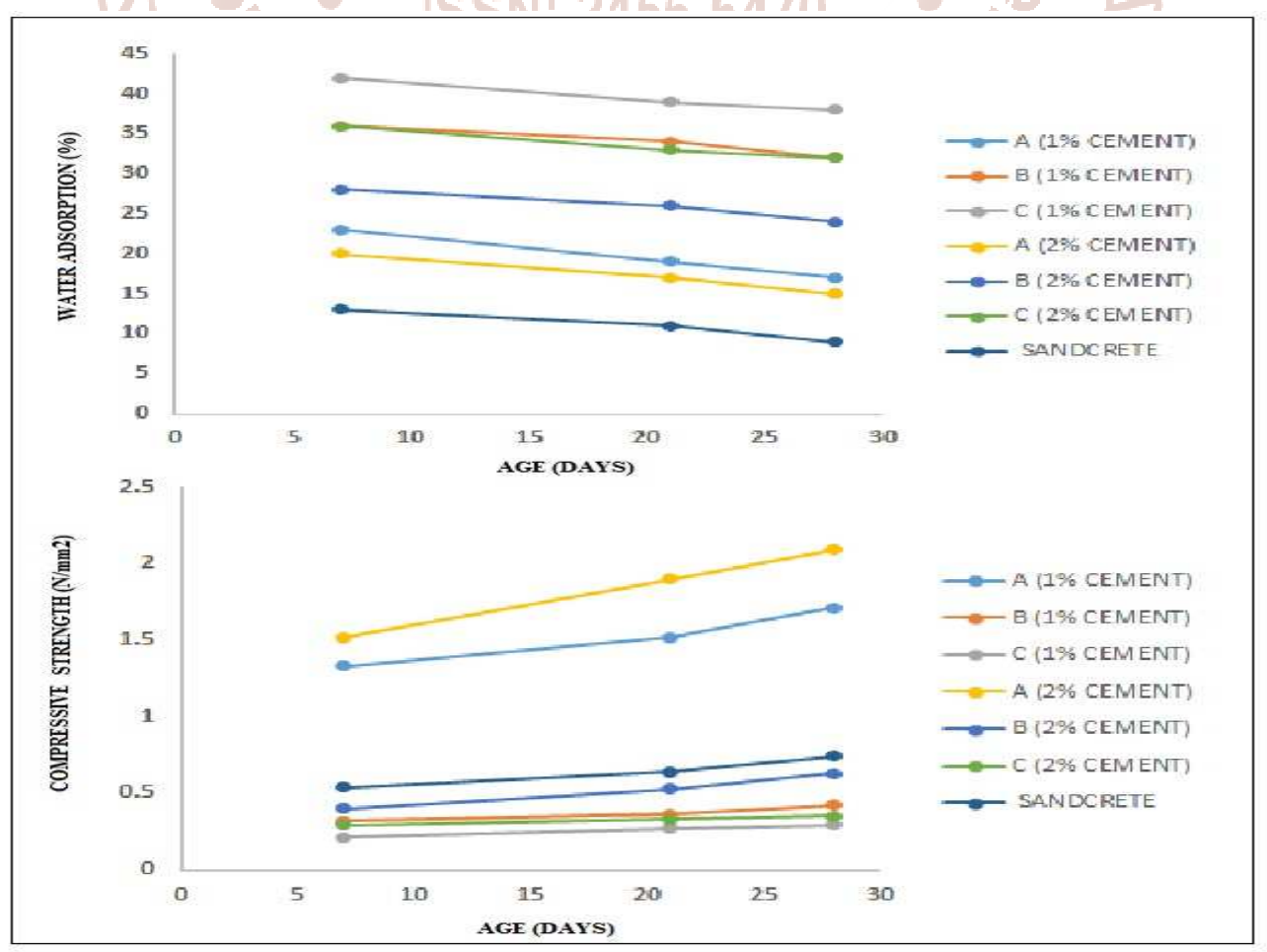

FIGURE 2: Graphs of Water Absorption And Compressive Strength For The Brick Samples 
Lateritic brick $\mathrm{C}$ has the lowest compressive strength values for all the numbers of days. The compressive strength also increases with age. It is also observed that the higher the cement content, the higher the compressive strength, this result is due to hydration. The compressive strength for all the materials were in order of A > SANDCRETE > B > C for both cement contents values.

TABLE 3: Abrasion and Impact Tests Results for The Soil Samples

\begin{tabular}{|c|c|c|}
\hline SAMIPLE & $\begin{array}{c}\text { ABRASION } \\
\text { TEST } \\
(\%)\end{array}$ & $\begin{array}{c}\text { IMIPACT } \\
\text { TEST } \\
(\%)\end{array}$ \\
\hline $\begin{array}{c}\text { SANDCRETE } \\
\text { HOLLOW BLOCK }\end{array}$ & 0.57 & 19 \\
\hline LATERITE BRICK A & 0.86 & 22.4 \\
\hline LATERITE BRICK B & 0.76 & 21 \\
\hline LATERITE BRICK C & 0.7 & 20.4 \\
\hline
\end{tabular}

Abrasion and Impact tests results were shown in Table 3, it is observed that the stabilized lateritic bricks $\mathrm{C}, \mathrm{B}$ and $\mathrm{A}$ have Abrasion test values of 0.7 , 0.76 and $0.86 \%$, respectively. While $20.4,21$ and $22.4 \%$ were Impact test values for lateritic bricks C, B and a respectively, Abrasion and Impact test values for sandcrete block were 0.57 and $19 \%$ respectively. The results showed that sandcrete hollow block has the lowest percentage of Abrasion and Impact due to its high cement content.

\section{Conclusion}

Lateritic brick $\mathrm{A}$ is stronger and lighter than sandcrete block. Water absorption rate decrease with increase in cement and age, Thus, increase in cement increase the strength of brick and reduce its water absorption. Lateritic brick is more cheaper than sandcrete block for construction of building because it require little cement content. Compressive strength of $2 \%$ cement content lateritic brick B and sandcrete hollow block are so close to each other in strength.
Based on the above conclusion, it is recommended that Lateritic brick A should be commercialized for industrial uses. Generally, Laterite brick should be used for low cost building because it has high compressive strength than that of sandcrete hollow block. Engineering properties of a typical lateritic soil should be investigated before being used for brick production. Research should carried out on another stabilizer other than cement for stabilization of bricks purpose.

\section{REFERENCES}

1. Raheem, A. A., Osuolale, O. M. Onifade, I. and Abubakar, Z., "Characterization of Laterite in Ogbomoso, Oyo State, Nigeria", Journal of Engineering Research, Vol 15 (2), pp. 73 -79, 2010.

2. Barry, R., "The Construction of Buildings", 7th edition, Vol 1, England: Blackwell Science, 1996.

3. Raheem, A. A.; Falola, O. O. and Adeyeye, K. J., "Production and Testing of Lateritic Interlocking Blocks", Journal of Construction in Developing Countries (JCDC), Vol.17 (1), 2012.

4. British Standard 1377 - BS 1377, "British Standard Methods of Test for Soils for Civil Engineering Purposes," UK, London: British Standards Institution, 1990.

5. Ekiti State Directorate of ICT, "The Official Website of the Government of Ekiti State, Nigeria,"

https://ekitistate.gov.ng/administration/local-govt/, 20, 2018.

6. Adetoro, A. E. and Abe, O. E., "Assessment of Engineering Properties of Ado-Ekiti to Ikere-Ekiti Road Soil, South-western Nigeria". WWJMRD, 4(6), pp. 191- 195, 2018.

7. Hodge, J.C., "Brick work", 3rd Edition, England: Edward Arnold Publisher. 